\title{
The Balai Terbang Dance: From Healing to Dance Movements
}

\author{
Widya Rizky Ananda ${ }^{1}$ Dr. Sutiyono, M.Hum² Fawziah Magfirah Z ${ }^{3}$ \\ ${ }^{12}$ Yogyakarta State University, Yogyakarta, Indonesia \\ *Corresponding author.Email: twidyarizkyananda@gmail.com
}

\begin{abstract}
This study introduces the Balai Terbang Dance from the Talang Mamak tribe as a ceremonial dance that grows, lives and develops in Indragiri Hulu Regency using qualitative research and a case study approach. The purpose of this study is to depict the Balai Terbang Talang Mamak Dance and its development in the current time in the Talang Perigi region of the Indragiri Hulu Regency in Riau. The Balai Terbang dance is created based on the local belief on the myth of the highest god, which is a swiftlet, that can cure diseases. The Balai Terbang dance was originally a simple movement used in the sacred healing ritual for the locals that are sick, as well as a form of getting rid of bad luck with the assistance of a shaman using a small house with plaited bird and coconut leaf above his head as properties. Based on the information obtained through observations, interviews and documentation, the Balai Terbang dance has now evolved from merely spontaneous movements to motions specifically choreographed to perform. As the medicinal movements has turned into beautiful dance movements, the dance can be enjoyed by everyone, including the people outside the region.
\end{abstract}

Keywords: Balai Terbang dance, healing ceremony, ritual

\section{INTRODUCTION}

Indonesia is a diverse country that is rich with various forms and types of art and culture. Nearly all Indonesian ethnic groups or tribes are known for their traditional art and culture which ultimately make up the nation's archipelagic art and culture. Each region has distinct forms and types of traditional art and culture that stands out from others and serves as the main characteristic or feature that defines the region.

The Riau Province has the Malays as their ancestors. Malay people have inhibited Riau land since a long time ago. Other tribes residing in this province include Laut, Sakai, Hutan, Talang Mamak, Bonei, and Anak Dalam. The Malay occupies most of Riau's mainland, while other tribes typically live in the remote area and the highland [1]. Among the great number of tribes in Riau, Talang Mamak is one of the tribes that live in the Indragiri Hulu Regency. Talang Mamak is a community isolated from the outside world who live traditionally in the interior of the forest and along the Indragiri River. The Talang Mamak people live in certain territories with their own cultural system, customs and customary laws. Their customs serve as a way of life, and those who violate the customs will be ostracized even to the point of being expelled from the tribe.

In the Talang Mamak tribe, cultural activities in the form of traditional games and art performances are called
Gawai. There are various Gawai ritual in the tribe, including Begawai, which is performed in traditional marriage ceremonies.

According to McFee, the main role of art is to maintain the concept of cultural reality through ritual and religious symbolism, to maintain customs and roles in culture through communicating status in clothing, architecture, and ornamentation and to enhance the appearance of existing cultures [2].

Dance has existed since the beginning of the human existence and is considered as one of the art forms needed by the human soul and mind. In the community, dance serves a means of entertainment, spectacle, and traditional culture that has social and religious functions. The Balai Tebang dance is originated from the Balai Terbang traditional healing treatment ritual by the Talang Mamak tribe, which is a part of the Riau province's mystical traditional cultural resources. Talang Mamak people are known to hold the animism and dynamism beliefs, meaning that the supernatural rituals are still a big part in their culture as they rely on the rituals to provide them with the things they need to deal with unsolvable difficulties they face in life.

Although the Balai Terbang treatment is aimed at healing one person, the ritual involves all members of the community to work together in order to create balance between the nature and human life that they believe.

Art that evolves in a community must be influenced by the life of the community. In other words, as the art form in a region evolves over time, the community must also 
experience some kind of transformations or changes during that time. Community participation is essential in preserving traditional culture and art [3].

There are some among the Talang Mamak tribe that struggles with their identity as a result of the modernization occurring in their surroundings. However, as a part of the Malay people, they still maintain their beliefs and customs. The Balai Terbang dance from this tribe receives very little exposure due to the lack of introduction to this traditional dance. For this reason, this study attempts to describe the development of the Balai Terbang dance today from the presentation aspect, as well as its functions.

\section{RESEARCH METHOD}

The method used in this study on Balai Terbang dance is a qualitative method with a case study approach. Qualitative research is research that produces descriptive data through observation and data collection through literature study techniques, observation, interviews and documentation. Meanwhile, case studies aim to understand and investigate a phenomenon in a real-life setting. The literature used comes from books and journals relating to ritual dance of dance. The phenomena faced by humans are facts, including social phenomena related to the art world. In this case, such social fact is commonly studied in a qualitative approach. All social facts can be described in a qualitative descriptive form [4]

The interview took place on June 3, 2019 and was conducted with Mr Kabuk as the informant. Mr Kabuk was a native of the Talang Mamak tribe and one of the cultural experts and activists who works to preserve Gawai in the Talang Mamak tribe.

Once the results of data collection were obtained, the data analysis was conducted. The data analysis technique used was that of Miles and Huberman, which consists of data reduction, data presentation, and conclusion. If the information obtained during the interview was found to be unsatisfactory, the researchers would ask more and more questions to the point that the answers were considered sufficient [5].

\section{RESULTS AND DISCUSSION}

\subsection{The Balai Terbang Dance}

The existence of art as one of the results of human creation is a reality developed by them which has lasted as old as the age of the humankind. It is undeniable that art emerges everywhere and continuously grows into the various kinds and forms, including dance. Like all kinds of art, dance offers and serves various interests based on the needs of the public at a certain time.

Performance arts, particularly dance, is one of the art forms that has a great influence that develops in the society. Dance is the kind of art that relies on movements and body as the medium that is both enjoyed by the dancer and the audience. Dance does not only serve as a beautiful set of movements with pattern, but also as a special characteristic of a certain region [6].

Traditional ceremonial dance relates either to the daily life of the people in the community or the customs applicable in the region where the art comes from. Traditional dance can be defined as the dance that is only performed at particular times and often associated with a traditional event or place or performed only for the purpose of the traditional culture only.

As a ceremonial healing dance, the Talang Mamak's Balai Terbang dance is one of the cultural resources in the Talang Perigi region in Rakit Kulim District, Indragiri Hulu, Riau. According to Mr. Kabuk, there are many kinds of traditional art and culture in the Talang Mamak tribe, inclusing Gawai, Perahu (Rentak Bulian Dance), Kajang Sirung, Balai Terbang, and Punduk Kubur. The most prominent art event in the Talang Mamak tribe is Gawai Gadang. Gawai is held once every 5 years and funded by government officials from the distribution of proposals based on the agreement among the custom council called Batin.

Based on the interview with Mr. Kabuk (June 3, 2019), the Balai Terbang healing ceremony is widely known and practiced among the villages of Talang Mamak tribe in the Indragiri Hulu Regency. This ritual uses spontaneous movements resembling the movements of the swallows as the worshipped creature. These movements are the basis of the Balai Terbang dance.

In the Talang Mamak tribe, the swallow is considered as the manifestation of one of the upper level gods (in fact, the highest-level god). The people of Talang Perigi believe that the swallow is capable of healing and treating sick people. This swallow god is what the tribe people pray to when they want healing or treatment for the sick. This belief has been around among the Talang Mamak people since the time of their ancestors.

This kind of belief on the myth of mystical power is strong in the tribe. According to Barthes, myth is a communication system in the form of messages, symbols, or shapes which is defined by historical limitations, requirements of use, and the community's response on the influence of the myth. Myth is not determined by the object of the message, but by the way the message is conveyed; the formal boundaries of myth are not 'substantial' [7].

According to Claude Levi-Strauss in Mitos, Dukun dan Sihir, a state experienced by an individual when losing consciousness and experiences an imaginary state is caused by certain factors. This situation is a state of psychological dissociation which is characterized by a lack of intentional movements and the occurrence of automatism in actions and thoughts. The state of unconsciousness is often exemplified by the state of hypnosis and "mystical mediums" (the personal condition serves as the medium of spirit news).

The Balai Terbang dance consists of the words balai and terbang. Balai refers to a miniature house decorated with a 
swallow ornament made from woven bamboo as well as woven coconut leaves. This little house ornament is to be placed on top of the head of the shaman as a property. The word terbang means "floating or flying in the air". Hence, balai terbang means a small house that floats or soars in the air.

Paul Radin describes healing dance, at least from the point of view of his leadership, as a drama that depicts the ideal life; the depiction of the myth with all of its coarser implications has been removed from the whole episode. The type of fictional drama that can manifestly present its achievements is only from people who have profound thoughts on the meaning of life as well as artistic skills to explain their views, and the free time they have, not by merely delivering it to the audience so that they accept it [8].

The Balai Terbang dance is originally performed by a shaman with the assistance of Bujang Bayu, whose task is to assist the shaman in the treatment of the sick while simultaneously serving as the player of the traditional instruments of gendang, ketobong, seramat, ketuk-ketuk and telempong.

For the Talang Mamak tribe, a shaman is both an expert in the supernatural world and a traditional healer. They are not only highly respected, but also feared due to their incredible supernatural powers, spells or incantations, and ability to heal the sick. In the tribe, shaman is the only hope for the people. In order to increase the power inside an individual, a shaman can provide them with objects which contain mystical powers, such as amulets or talismans. These objects have been gifted with spells that supposedly can prevent the user from harm. They may take the form of kris, bracelets, necklaces, spears, etc. It is also the shaman who determines the kind of ceremony to be conducted, the requirements for the ceremony, the good time for the ceremony, as well as the place.

The Balai Terbang ritual is typically performed in a field. The shaman is dressed in black pants, a robe, bare chest, a head band, and a long cloth, while wears black shorts. The dancers apply gagah makeup.

The spells used in the dance aim to summon the god so that the god can provide a clue on what treatment is needed. The spells are as follows:

Burung kacik burung cawang
Terbang tinggi menyisih awan pateh
Nak terbang tinggi ke pungguk batu
Betimbun sengkarek basih
Terbang rendah teranju-anju
Terbang tinggi tak ke pasir
Terbang belancuh sang layang-layang

Some types of birds (hornbills, cawang) are sacred for the Talang Mamak people and can give them blessings

No matter how high the bird flies up to the white clouds

They will return to the forest

Flying low hugging the ground (earth)

Flying high to remember to return

Flying and soaring above the swamps

The movements of the Balai Terbang Dance are as follows. 1. Flying Bird Motion

The shaman stands behind the patient and performs a set of movements as if he was flying using a long cloth while holding up the balai, which is followed by Bujang Bayu behind him doing the same movements.

2. Worship / Greetings

After doing the wild movements, the shaman and Bujang Bayu step in front of the patient by making a gesture of prayer to ask permission from the natural powers to carry out the treatment.

\section{Flying Bird Motion}

After performing the prayer gesture, the shaman returns to do a movement which resembles a bird flying towards the patient. The position of the patient is in the middle of the ceremony. Bujang Bayu takes the offerings prepared prior to the ceremony and carried them to the patient.

4. Recitation of Mantra

The shaman is behind the patient while reciting a mantra over the patient's head, Bujang Bayu still holds the offerings. The patient here undresses as a form of expulsion from the disease.

5. Smoking

The shaman begins to smoke the patient with his palms all over the patient's body. Then, he takes a long cloth that has been infused with an incense and rubs it onto the patient's head and body to see the patient's illness. Bujang Bayu sprinkles dry corn on the shaman and the patient.

6. Healing

The shaman heals the patient by covering the patient's head with the long cloth, while reciting a mantra. Then, he throws things up and to the side, and stands slowly while pecking the patient with a bird.

7. Pecking

The shaman and Bujang Bayu perform the same wild movement around the patient and return to their original position (behind the patient).

8. Flying Bird

Shaman and Bujang Bayu move towards the music players. 9. Pecking

The shaman does a pecking movement on the music players with a bird with the intention to prevent the disease on the music player. This movement signifies the end of the Balai Terbang healing ceremony.

Translated as: 


\subsection{The Development of the Balai Terbang Dance in the Indragiri Hulu Regency}

As social creatures, people constantly experience absolute social transformations anywhere they live. These changes, whether positive or negative, ultimately affect the people, both in the urban and the rural areas. Changes occur not only to society who live in an advanced civilization, but also to those who some may consider less advanced such as the Talang Mamak tribe. Talang Mamak people are a part of the Malay people who still retain their traditional beliefs and customs despite simultaneously experiencing a struggle to hold on to their identity due to fast-paced modernization process occurring in their surrounding habitat.

Gillin and Gillin define social transformation as a variation of the accepted way of living, whether due to the geographical changes, materialism culture, composition of the population, ideological changes, or diffusion or new findings in the society [9]. These changes can also be referred to as a development which happens as a result of the maturity process and experiences. According to Van den Daele, development refers to a qualitative change. This means that development is not necessarily associated with the addition or improvement of a certain aspect, but a process of integration of many complex structures and functions [10].

In theory, cultural development has a close relation with the development of the life pattern of the culture's supporting factors, including politics, economy, and the social state affected by globalization. Based on these notions, this study investigates the development of the Balai Terbang dance, which consists of the elements in the dance composition.

The development of the dance is still based on the traditional Balai Terbang ceremony which is preserved by the Talang Mamak people as it remains a sacred ritual for them. This sacred dance ritual then transforms into an aesthetic dance to be performed in public. In this sense, the transformations occur in the movement, music accompaniment or arrangement, costume design and makeup, as well as floor pattern.

Essentially, the Balai Terbang dance grows, lives and develops in the remote area of a remote village. In terms of quality, the Talang Mamak tribe considers art not as a form of entertainment, but a sacred ritual related to their beliefs on the relation between mystical power and human beings. For the tribe, ceremonial dance serves as a medium for offering and worshipping the higher powers in order to get protection, safety, ability to communicate with nature, healing illnesses, happiness and welfare among the community, as well as casting out evil spirits.

A study conducted by Moh. Hasan Bisri [11] supports this research on how among primitive societies, dance is commonly used as a means or medium to meet a particular need or pray for a certain wish and believed it to work. Similar to the current study, the ceremonial dance also serves as a means of worshipping and giving offerings to the higher powers in order to get protection, safety, ability to communicate with nature, healing illnesses, happiness and welfare among the community.

In the treatment process, dance movements are not an essential or mandatory part that must be performed sequentially as it is up to the shaman's belief and decision. Not all movements must be performed in the healing ceremony. If few of the movements are sufficient to receive hints from the gods, there is no need to perform the rest of the dance. However, in the dance performance, the movement sequence has been designed in order to reveal the beauty in the dance movements so that the audience may fully appreciate the performance.

The in-depth interview conducted with Mr. Kabuk on June 3, 2019 provides great details on the daily life and art activities in the Talang Mamak tribe. The Balai Terbang healing ritual has transformed from the belief of the Talang Mamak people on the powers of the swallow as one of the noble creatures that can heal the sick into a dance that is performed to welcome guests as a form of entertainment.

On the highest-level god of the Talang Mamak tribe, Andrew Lang's theory points out how such religious behaviors among humans typically occur due to a certain enlightenment from the gods, which ultimately unravels the mythologies of various tribes and nations across the world.

In the mythological tales, Andre Lang often discovers the presence of the highest-level god, the creator of the universe and the guardian of natural balance. The belief on such figure exists among tribes with low level of civilization and live from hunting and gathering.

In regard to the ritual dance, the current research discovers a study by I Wayan Dana [12] entitled Paruman Tapakan Baron in the Tapak Pertiwi Ritual, which is about the rituals of uniting the powers of the god through the his symbol (Perusa) and the symbol of the goddess Dewi Pertiwi (Pradana). The unification of these two holy powers is what generates the motion of life and the purification of the universe from all negative influences that threaten the lives of humankind.

Scholar Catherine Bell argues that the abstract concept of "ritual" as a cross-cultural phenomenon has been developed by scholars whose research has eventually had a significant impact on how people perceive rituals. In this relativistic view of rituals, individuals create or modify rituals while "destroying" some forms of traditional ritual authority [13].

In the healing ritual process, many preparations are needed. Likewise in the Balai Terbang healing ceremony, the person who requests for the ceremony must prepare some offerings based on the shaman's instruction, consisting of the balai, incense, dried corn, woven young coconut leaves, coconut leaves in the form of a bird, a house, charcoal, a long piece of cloth, a mat made of pandan leaves, live chickens, roast chicken, eggs, candles, turmeric rice, and coconut (palm) buds to hang in the house. All the requirements requested by the shaman are important components in supporting the steps of the healing ceremony. However, public confidence in the ability of the 
shaman also influences the success of the shaman's treatment.

The shaman first determines the best place and time to carry out the treatment ceremony. Usually the ritual of treatment is carried out in the house, but it can also be carried out in front of the yard, according to instructions from the god through the dukun as an intermediary who will help treat the patient. Offerings are given to the god summoned. The ceremony can be adjusted to the needs. For instance, a ceremony to prevent harm and bad deeds can also be performed on the field. The appropriate time to conduct this kind of ceremony usually begins at midnight. The shaman must first know the type of illness of the patient, which can be learned by divination. The shaman will be assisted with Bujang Bayu and the community since the preparation until the ritual is completed. Those who can serve as Bujang Bayu are the relatives of the shaman. The ritual takes place from making the balai and preparing the ceremonial needs. In the process, the shaman's intense concentration may cause him to go on a trance as his behaviors, movements, and voice change. The one who dance, sings, and looks for the cure is no longer a mere human being, but one that has become one with the higher power.

Trance occurs in the Balai Terbang dance as the shaman has become one with the mystical power, resulting in a change in his behaviors. The characteristics of trance include uncontrollable movements (increasingly faster or slower), red eyes, and a change in the voice. Whether the god gives the shaman what he asks for can only be found out once the shaman has been conscious, which is assisted by Bujang Bayu. The conscious shaman loses his energy and looks incredibly exhausted.

It can be seen that the Balai Terbang dance involves elements of art including movement, music, costume, and properties. Traditional dance typically has a distinct feature that signifies the characteristic of the region that is visible through the pattern of dance movements that has been established since a long time ago. The choreography in the Balai Terbang dance does not particularly show a harmonious and aesthetic composition as the dance aims to depict a distinct healing ritual with raw movements.

The element of motion in the Balai Terbang dance consists of simple movements as the shaman moves the way a bird flies, holding up the balai above his head. In the transformation, an aesthetic motion is added to the movement. The shaman movements with the Balai Terbang show that the shaman is settled worshipping the balai, and conveying the message to the public that the shaman has officially been settled and ready to find the cure, get rid of the disease, and cast out the evil spirits.

In the Balai Terbang ritual, the shaman is dressed in black pants, a robe, bare chest, a head band, and a long cloth, while wears black shorts. The dancers apply gagah makeup. The music players play the traditional instruments of gendang, ketobong, seramat, ketuk-ketuk and telempong. The properties are used as a symbol of the ritual dance. Today, the Balai Terbang dance is performed in an open field based on the request to welcome guests.
The traditional belief model adopted by the Talang Mamak tribe at least began to undergo transformation in the 20th century. The practice of worshiping ancestors has not been carried out anymore because of the invasion of religion teachings that incorporate education. At the moment, most of the Talang Mamak tribe community has converted to Islam.

The presence of the Balai Terbang dance among the Talang Mamak community serves as a part of a tradition that has prevailed in their lives from generation to generation and functions as a healing ceremony or for casting out evil spirits. Today, the Balai Terbang dance is not only performed for healing ceremonies or to cast out evil spirits, but also for entertainment in welcoming guests in other traditional ceremonies by removing the offerings, although the charcoal and incense are still used for the smoking procession in the healing ritual. In this sense, Balai Terbang dance is expected to be an attractive dance for the youth as it contains aesthetic values in the dance performance.

The shift that occurs in the Balai Terbang dance also happens to traditional dances in other regions. A study by Nelly Kornellya, Imma Fretisari and Henny Sanulita [14] shows the shift in function of the Besagu Ayu dance from a traditional cultural treatment ritual of the Dayak Kantu tribe to a dance performed for the public. Similarly, the Balai Terbang dance has experienced a transformation in terms of presentation and function, namely from a ritual dance to an entertainment dance for welcoming guests. The shift of the traditional dance in the postmodern era is inevitable as the preservation of culture becomes the main reason for the development of traditional dance.

\section{CONCLUSION}

As a dance of healing illnesses and casting out evil spirits, the Balai Terbang dance consists of elements of art, such as movements, music, costumes, and other properties. For the Talang Mamak tribe, the swallow has the power of healing the sick.

In the past, Balai Terbang dance is a sacred dance with movements solely used in the healing ritual for either serious illness or other common diseases, as well as casting off evil spirits. Today, the dance can be appreciated by a wider audience as it is performed for welcoming guests and serves as an entertainment for others. The movements of the dance have been standardized and the dance is performed without offerings. Nevertheless, the Balai Terbang healing ritual that is supported by the shaman and the custom council is in fact still available for the public and those who ask for it, particularly in the Talang Mamak tribe.

\section{REFERENCES}

[1] Farukhi dan Vida Afrida, Mengenal 33 Provinsi Indonesia [Recognizing 33 Provinces of Indonesia] : RIAU. Jakarta: PT. Sinergi Pustaka Indonesia, 2008. 
[2] Craig, Jayne Ellen, Ed.D, “A philosophical For ArtEducational Curiculum”. Illions State University. Terjemahan, 1992.

[3] Pujiwana, Pembinaan Paguyuban Seni Tradisional [Assisting Traditional Arts Association]. Yogyakarta: Almatera, 2010.

[4] Sutiyono, Fenomenologi Seni. Meneropong Fenomena Sosial Dalam Kesenian [Observing Social Phenomena in Art] Yogyakarta: Insan Persada, 2011.

[5] Sugiyono, Metode Penelitian \& Pengembangan [Research \& Development Methods]. Bandung: Alfabeta, 2017.

[6] Sedyawati, Edi. "Pengetahuan Elementer Tari dan Beberapa Masalah Tari [Basic Knowledge of Dancing and Several Problems in Dancing]." Jakarta:

Departemen Pendidikan dan Kebudayaan (1986).

[7] Barthes, Roland, Mythologies. Yogyakarta: Kreasi Wacana. Terjemahan, 2004.

[8] Royce, Peterson Anya. Antropologi Tari [Dance Anthropology]. Sunan Ambu Press STSI, Bandung, 2007.

[9] Soekanto, Soerjono, Sosiologi Suatu Pengantar [Sociology: An Introduction]. Jakarta: Rajawali Pers, 2012.

[10] Hurlock, Elizabeth B. "Psikologi perkembangan [Developmental Psychology]." (1980).

[11] Moh Hasan Bisri, The Development Of Ritual Dance Toward Pseudoritual Dance In Surakarta.Harmonia, Journal Of Arts Research and Education; Vol 8, No 1, 2017.

https://www.neliti.com/publications/66343/perkembang an-tari-ritual-menuju-tari-pseudoritual-di-surakarta-thedevelopment-o\#cite

[12] Dana, I. Wayan. "Paruman Tapakan Barong dalam Ritual Tapak Pertiwi [Paruman Tapakan Barong in Tapak Pertiwi Ritual]." Resital: Jurnal Seni Pertunjukan 11.2 (2010).

http://www.journal.isi.ac.id/index.php/resital/article/vie $\mathrm{w} / 510$

[13] Clanton, Amy. "Ritual Art: Political, Social and Religious Subversion in the Dramatic Works of William Butler Yeats and Aleister Crowley." FORUM: University of Edinburgh Postgraduate Journal of Culture \& the Arts. No. 17. 2013.

http://www.forumjournal.org/article/view/684.
[14] Kornellya, Nelly, Imma Fretisari, and Henny Sanulita. "Pergeseran Fungsi Tari Besagu Ayu Pada Suku Dayak Kantu'di Kapuas Hulu Kalimantan Barat [The Shift in Besagu Ayu Dance Functions towards Dayak Kantu 'tribe in Kapuas Hulu, West Kalimantan] ." Jurnal Pendidikan dan Pembelajaran 6.12.published. 